\title{
IN'TERNA'TIONAL CITIZENSHIP.
}

BY THE HON. CHARLES CARROLL BONNEY.

THE Constitution of the American Republic provides that: "The citizens of each state shall be entitled to all privileges and immunities of citizens in the sezeral states." (Art. I2. Sec. 2.)

The privileges and immunities embraced in this provision are such as belong to general citizenship, and include the right of travel and the conduct of trade and commerce, with protection in the enjoyment of "life, liberty and the pursuit of happiness" in any lawful employment, subject to such regulations and restraints as the State may deem it proper to impose upon its own citizens for the general welfare, under what is termed the police power. The provision does not include the right to vote and hold office, or otherwise participate in the government of the State, but only to enjoy, equally with its own citizens, the established liberties of movement, residence, occupation, acquisition, and disposition; with just protection in person, property, and privileges. In effect, this provision makes the citizens of each State, citizens of the United States, for all the important purposes of human life, as by other provisions of the national constitution the citizens of the several States are made citizens of the Republic for all the purposes of the national government. Without entering into distinctions not material to the present purpose, such may be said to be the object and effect of the nineteen words of the American Constitution of government that made the inhabitants of all the States practically one people. Before the Union, the American States were foreign to each other, and the citizens of each, aliens in all the rest, without rights, privileges or immunities, save such as might be accorded by international comity.

By the early Roman law, it is said that an alien "had no right that the citizen was bound to respect." But this harsh rule was 
afterward modified by a protection given by a citizen as patron, to an alien as his client, and by treaties under which foreigners were accorded certain rights and privileges; and soon a body of private international law, called the Jus Gentium, began to take its place beside the civil law, and to afford a basis of what is termed natural justice, for the determination of controversies between citizens and aliens. This universal jurisprudence of mankind has advanced from age to age, until it now commands the approval of the enlightened world, and affords a rational basis of intercourse between the peoples of different countries. In return for the protection given to an alien, he owes a ready and complete obedience to all the laws for the preservation of the peace and good order of society, and must conduct himself in conformity to the general law and public policy of the country whose privileges he enjoys. The general rule is that an alien may acquire and hold personal prop. erty, and have the aid of the judicial tribunals for its recovery and protection, but that he cannot acquire and hold an indefeasible title to land, without an enabling act, authorising him to do so.

An alien, lawfully sojourning or domiciled in a foreign country, is entitled to the aid of his own government for his protection against any invasion of his just rights and privileges, by or under the sanction of the foreign government.

But while many of the rights and privileges of citizens in foreign lands have finally come to be well understood and established, many others are still obscure on the subject of controversy, as diplomatic discussion abundantly shows. ${ }^{1}$ At the same time there has been an enormous increase of travel and commerce throughout the world, accompanied by an ever-growing demand for better facilities and more adequate security to visiting or trading strangers. More swiftly than any of us can well realise, the whole world is becoming in fact one great country, needing new laws for the proper protection of its vast and varied people.

Let us then inquire whether the time has not fully come for an extension of the principle of the guaranty of equal privileges and immunities to the citizens of all the states of the American Union, to the citizens of all the enlightened countries of the world, so far as travel, residence and commerce are concerned; and for a distinct statement of those privileges and immunities in a Code of International Intercourse to be prepared by representatives of the participating countries, and adopted by treaty by the respective governments? Such a code is necessary both for the information

1 Dainese v. Hale, 91 U. S. R. 13; 2 Whart. Int. Law Dig., Sec. 171 et seq. 
of those concerned, and to avoid disputes among the nations in regard to the rights and privileges accorded.

There are two distinct aspects of the case for which provision should be made. We have thus far had in view only the first, namely, the admission of aliens to certain rights and privileges of citizens. Let us now turn to the second, which is the recognition and protection of certain rights and privileges which the alien enjoys in his own country under its laws and public policy, and which he desires to take with him, wherever he may journey throughout the world. It is obvious that no nation will protect an alien in the enjoyment of any privilege that would disturb the peace and good order of its own society. But there is no good reason why any government should not accord to the citizen or subject of any foreign power with which it is at peace, the privilege of living according to the customs and laws of his own country, so far as he can do so without any such disturbance; and of dealing with his own countrymen according to the laws that govern them at home. Indeed, one of the charms of international intercourse is the preservation by visitors from other countries of their national characteristics, and the harmonising of different systems of culture and progress, in the relations established between natives and sojourning foreigners. But all such visitors should be distinctly informed, by a clear and explicit code of rules, of the privileges accorded and those denied to them.

A citizen who desires to be assured of the protection of his own government in a foreign land to which he may lawfully go, should take with him a passport from his own government certifying his good character, and providing convenient means of identification, and directions for inquiry or report in relation to him, if occasion should arise.

In case of any controversy between an alien and the government under which he is sojourning, or between him and a citizen, or between him and a fellow alien, or between him and an alien of another country, the International Code should distinctly specify the tribunal by which, and the mode in which the dispute shall be tried and determined; and as all such provisions would be reciprocal, there would be the strongest incentive to provide the most expeditious, inexpensive and efficient means practicable, for the enforcement of rights and the redress of wrongs.

Such a Code of International Intercourse would practically establish a general citizenship of the world, whose rights and privileges could be acquired and enjoyed by any worthy citizen of any 
enlightened country. Many beneficent results would follow. Many annoying obstructions to free intercourse would be swept away. Travel and commerce would largely increase. A sense of safety and security would prevail in many cases where now the perils of travel, sojourn or trade outweigh all the pleasure or profit they might yield.

In no other way than by such an International Code, is it practicable to provide reasonable and satisfactory safe-guards against hostile movements made under the guise of innocent travel or lawful trade. Requiring each government to guarantee the good conduct of its own citizens, travelling or trading under its passport, in a foreign country, would naturally make that government careful not to issue such a guaranty to any unworthy or suspicious character. The right of a government to demand protection of its citizens or subjects in a foreign land, and to enforce that demand if need be, even by war, necessarily involves the responsibility of that government for the good behavior of such citizen or subject, and the right of the government of the foreign country to enforce that responsibility. If citizens of any country would travel, sojourn or trade in any other, under the protection of their own home government, that government should be as ready to punish them for any misconduct or offense, as to secure the proper redress for any injury that may be inflicted upon them by any official or private person of the foreign country. Unfortunately this plain rule of reason and justice has not always been observed.

Cases are not wanting in which it has been charged that foreign citizens or subjects have suffered outrageous treatment at the hands of resident representatives of other powers, and were utterly unable to obtain any remedy for their wrongs, because the local tribunals had no jurisdiction, and the government that sent the representative had not provided any proper way of learning the facts, much less any adequate mode of administering justice and enforcing the law. Surely it is not too much to ask that matters of so much importance to private interests and the public welfare in all enlightened countries should now receive better practical attention than has hitherto been given them; and that the leaders of government in all such countries unite to secure the speedy appointment of an International Commission to frame a code of International Intercourse.

Naturally such a work would involve, before its completion, a reconstruction of the present highly inefficient and unsatisfactory 
systems of foreign service, and would lead the way to great improvements in all departments of international relations.

If the old statesmanship of diplomacy and war cannot see the importance and feasibility of the proposed advance, it will, nevertheless, not be long delayed, for the new statesmanship of law and justice will, at no distant day, become dominant in the world, and among the blessings it will bring, will be found that which for want of a better term may be called International Citizenship, with welldefined rights, privileges, duties and liabilities, alike of the persons and the governments concerned, with clearly specified tribunals and modes of proceeding for the speedy and adequate determination of whatever questions may arise in the course of travel, sojourn, commerce, or official relations.

The final triumph of international comity may be delayed, but it cannot be prevented. The time will come when the travelling or sojourning citizens of all friendly powers properly accredited by their respective governments will be entitled, in the countries where they may journey or temporarily reside, to all the privileges and immunities of citizens thereof, except those of a political nature, and such others, if any, as may for any special reason be expressly withheld by public law or proclamation. The old rule will be reversed, and the privileges of the alien will be limited, not by what is granted, but by what is withheld.

The Jus Gentium of the Roman law, founded on what have been termed the principles of natural justice, involved, however deeply concealed, the ultimate recognition of the right of all men, irrespective of citizenship, to be protected in rational intercourse with their fellow-men. The great work of Hugo Grotius on the Laws of War and Peace, in 1625 , marked the beginning of a new era of International Law, founded, as was declared by Great Britain in 1753 , upon justice, equity, reason and convenience. The new movement has steadily advanced, and now has a strength and activity hitherto unknown. It cannot fail to go forward with everincreasing power and majesty, till, in the impressive language of Prof. August von Bulmerincq, of the Univerity of Heidelberg, "a universal law will take its course around the world and attain universal supremacy; not the Roman law, but a law based upon the principles and modes of thought of modern civilisation,-a cosmopolitan law." Under that cosmopolitan law, universal and supreme by compact of all enlightened powers, law-abiding man will have the well-defined right to go where pleasure or interest may lead him, throughout the world, assured that he will be adequately protected by all nations, as occasion may require, in the full enjoyment of all the just privileges and immunities of an International Citizenship. 